\title{
Sexually transmitted infections among Pakistani pregnant women and their husbands in Norway
}

This article was published in the following Dove Press journal:

International Journal of Women's Health

4 September 2010

Number of times this article has been viewed

\author{
Soen Eng Yap Bjerke ${ }^{1,2}$ \\ Ellen Holter ${ }^{3}$ \\ Siri Vangen ${ }^{2,4}$ \\ Babill Stray-Pedersen ${ }^{1,2}$ \\ 'Medical Faculty, University of \\ Oslo, Oslo, Norway; ${ }^{2}$ Women and \\ Children's Division, ${ }^{3}$ Department \\ of Microbiology, Oslo University \\ Hospital, Rikshospitalet, Oslo, Norway; \\ ${ }^{4}$ National Resource Centre for \\ Women's Health, Oslo, Norway
}

Correspondence: Soen Eng Yap Bjerke

Trivind Health Center,

3540 Nesbyen, Norway

Tel +47 32070230

Fax +473207 0253

Email eng@online.no
Aim: To assess frequency and determine the factors associated with Chlamydia trachomatis, herpes simplex virus type 2, and hepatitis B seropositivity among Pakistani pregnant women and their husbands in Norway.

Methods: All together 112 couples of Pakistani origin living in Norway participated in our study. Blood samples were tested for immunoglobulin $\mathrm{G}(\mathrm{IgG})$ antibodies against $C$. trachomatis, herpes simplex virus type 2 , and hepatitis B.

Results: Pakistani women had significantly lower age, education level, and years of residence in Norway compared to their male partners. Among the men, $12 \%$ had positive chlamydial IgG antibodies in contrast to $1 \%$ of the women. These couples were discordant, meaning that the 13 wives of positive men were not infected with $C$. trachomatis, and the husband of one positive woman was not infected either. Four percent of women and $2 \%$ of men were positive for herpes simplex type 2 . Only one couple was concordantly positive for herpes simplex type 2 , the remaining four couples were discordant. Twelve percent of women and $21 \%$ of men were, or had been, infected with hepatitis B.

Conclusion: Sexually transmitted infections did not seem to be prevalent in Pakistani immigrant couples in Norway. However, it was striking that most couples were discordant. Pakistani immigrants should be offered hepatitis B vaccine.

Keywords: Chlamydia trachomatis, herpes simplex virus type 2, hepatitis B, Pakistan, Norway

\section{Introduction}

The population of Norway was relatively homogeneous until 1970. Thereafter, a considerable migratory influx of immigrants, particularly from Asia and Africa has occurred. People originating from Pakistan constitute the largest immigrant group from low income countries, representing $7 \%$ of the total Norwegian population. Most of them live in Oslo and the suburbs. ${ }^{1}$ The first Pakistani men came as economic immigrants in the late 1960s. After restriction for working purposes was imposed in 1975, immigration from Pakistan has mainly been for marriage and reuniting family, and consanguineous marriages are common.

Sexually transmitted infections (STIs) have shown an alarming increase in Asia and Africa. ${ }^{2}$ Ethnic variations in the rate of diagnosed STIs have been reported in many developed countries. Indian and Pakistani women and men had lower prevalence of diagnoses STIs than black Caribbeans and black Africans in Great Britain. ${ }^{3}$ In Norway, the typical STIs such as syphilis and gonorrhea are very seldom, while herpes simplex virus type 2 (HSV-2), Chlamydia trachomatis, and human papillomavirus are prevalent especially in the young generation. ${ }^{4}$ 
Individual sexual behavior is a key determinant of STI transmission risk, but alone does not explain the varying risk across ethnic groups. There is a need for targeted and culturally competent prevention interventions. ${ }^{3}$

C. trachomatis is a major cause of ocular and sexually transmitted diseases worldwide. ${ }^{5}$ Women sustain the most severe consequences of untreated infection, including pelvic inflammatory disease, chronic pelvic pain, ectopic pregnancy, and tubal infertility. Most chlamydial infections are asymptomatic. ${ }^{6}$ In Norway, $84 \%$ of young females below 25 years of age have been tested and $9 \%-11 \%$ have been positive, while among the $44 \%$ tested young adult males, $21 \%$ have been positive. $^{?}$

HSV-2 is the leading cause of genital ulcer disease worldwide. HSV-2 infection also represents a risk factor for the acquisition and transmission of human immunodeficiency virus (HIV). ${ }^{8}$ A serious consequence of HSV-2 infection is the transmission of the virus from an infected mother to a neonate, usually intrapartum. Neonatal infection can cause long-term sequalae and even death. ${ }^{9}$ In Norway, $14 \%$ of the pregnant population have been tested HSV-2 positive. ${ }^{10}$

Hepatitis B virus (HBV) infection is a major health problem globally including Pakistan. ${ }^{11}$ HBV may lead to severe chronic infection and hepatocellular carcinoma. Fifty percent of infections are thought to be acquired by sexual contact. ${ }^{12}$ In countries where HBV is endemic, vertical spread plays a major role. ${ }^{13}$ Among ethnic Norwegians, hepatitis B carriership is rare $(<0.5 \%) .{ }^{14}$ The frequency among immigrants may reflect the situation in their home countries, but must also take into account the situation in the new country.

Studies of STIs among immigrants to Europe are mainly focusing on syphilis and HIV, and not the more common STIs. ${ }^{15}$ Our aim was to take an in-depth look at STIs like C. trachomatis, HSV-2, and hepatitis B among our Pakistani immigrants in Norway.

\section{Material and methods}

The Pakistani women who came to prenatal ultrasound screening at $17-18$ weeks of gestation in the two maternity hospitals in Oslo (Rikshospitalet and Ullevål University Hospital) were randomly included. The first author visited Oslo once a week over two years for interviewing and blood collections of the Pakistani women and their husbands. We included 112 Pakistani pairs, after getting their personal consent and signature. They lived in Oslo city or one of the suburbs. The samples, collected in ethylenediaminetetraacetic acid tubes, were separated, and plasma was frozen at $-20^{\circ} \mathrm{C}$.
In 2009, we analyzed the immunoglobulin $\mathrm{G}(\mathrm{IgG})$ antibodies to C. trachomatis, HSV-2, and HBV. If the antibody to the core antigen of HBV (anti-HBc) IgG was present, we analyzed also the surface antigen of HBV (HBsAg) and the antibody to the surface antigen of HBV (anti-HBs).

Analysis of $C$. trachomatis was performed with SeroCT ${ }^{\mathrm{TM}}$ IgG (Savyon Diagnostics, Ashdod, Israel). Analysis of HSV-2 IgG was performed with HerpeSelect ${ }^{\mathrm{R}} 2$ Elisa IgG (FOCUS Diagnostics, Cyprus, CA). Analysis of anti-HBc, HBsAg, and anti-HBs were performed with chemiluminescent immunoassay (Abbott Laboratories, Abbott Park, IL).

IgG measurement were registered as "negative", "grey zone" meaning neither negative nor positive, "slightly positive" meaning that specificity may be uncertain, and "positive". In our study we regard "grey zone" as "negative" and "slightly positive" as "positive".

The study was approved by the Regional Committee for Ethics and Research and the Data Inspectorate.

\section{Variables}

A structured questionnaire was used. Information about demographic and socioeconomic factors such as age, marital status, relationship, educational level, parity, family income, and years of residence in Norway were registered.

\section{Statistical analyses}

All data were registered in SPSS (SPSS Inc, Chicago, IL). Descriptive statistics (including means, standard deviations [SD], frequencies, and percentage) were used to analyze distribution of the demographic variables.

Differences in demographic and serologic results between men and women were tested with Fisher's exact test. Signifier level of $P<0.05$ was used. The relationship between seroposivity of $C$. trachomatis, HSV-2, and hepatitis B and determined factors were estimated by logistic regression analyses and presented as crude odds ratios with $95 \%$ confidence interval.

\section{Results}

Significant differences were observed in age, level of education, and time of residence in Norway between men and women. The average age for Pakistani women was 27.5 years (range 18-44 years; SD 5.4 years), and 32.7 years for their husbands (range 18-56 years; SD 7.9 years). Consanguineous marriages were common (70\%), 47\% were cousins (close relatives), and 23\% were distant relatives. None of the women were educated at university level while $12 \%$ of the 
men had tertiary education. The family income was within the Norwegian average for $57 \%$ of the participants. Two thirds $(67 \%)$ of the men had lived more than 10 years in Norway. Twenty seven women (24\%) had recently arrived in Norway compared to eight men (7\%) (Table 1).

\section{Serologic results}

Differences between men and women were also found in seropositivity of C. trachomatis, HSV-2, and hepatitis B. Due to low prevalence, the differences did not reach significance. Thirteen men (12\%) had chlamydial IgG antibodies, while only one woman (1\%) was positive. This woman was 31 years old, had lived two years in Norway, had low educational level (less than nine years schooling), and the family had low income. All positive cases occurred in discordant couples, meaning that the 13 wives of the positive men were not infected with C. trachomatis, and the husband of the one positive woman was not infected either (Table 2).

There were no differences in ages and educational levels of the chlamydial IgG positive and negative men. Of the 13 positive men, $69 \%$ had high income.

Four women (4\%) and two men (2\%) were positive for HSV-2. Only one couple was both positive for HSV-2, the remaining four couples were discordant (Table 2).

Table I Demographic characteristics of I I 2 Pakistani immigrant couples living in Norway

\begin{tabular}{|c|c|c|c|c|}
\hline & Couples & Women & Men & Test \\
\hline Total & 112 (100\%) & $112(100 \%)$ & $112(100 \%)$ & \\
\hline Age in years (mean) & & 27.5 & 32.7 & $P=0.00 I^{*}$ \\
\hline \multicolumn{5}{|l|}{ Consanguinity } \\
\hline Close relative & 53 (47\%) & & & \\
\hline Distant relative & $26(23 \%)$ & & & \\
\hline No relative & $33(30 \%)$ & & & \\
\hline \multicolumn{5}{|l|}{ Educational level } \\
\hline$<9$ years of school & & $30(27 \%)$ & $17(15 \%)$ & \\
\hline 9 years of school & & $29(26 \%)$ & $19(17 \%)$ & \\
\hline High school level & & 53 (47\%) & $63(56 \%)$ & \\
\hline University level & & 0 & $13(12 \%)$ & $P=0.00 I^{* *}$ \\
\hline \multicolumn{5}{|l|}{ Number of children } \\
\hline I child & 32 (29\%) & & & \\
\hline$>$ I child & 80 (7I\%) & & & \\
\hline \multicolumn{5}{|l|}{ Family income, NOK } \\
\hline$\leq 200,000$ & 41 (37\%) & & & \\
\hline $20 I-400,000$ & $64(57 \%)$ & & & \\
\hline$>400,000$ & 7 (6\%) & & & \\
\hline \multicolumn{5}{|l|}{ Years of residence } \\
\hline \multicolumn{5}{|l|}{ in Norway } \\
\hline$\leq 1$ & & $27(24 \%)$ & $8(7 \%)$ & \\
\hline $2-9$ & & 48 (43\%) & $29(26 \%)$ & \\
\hline$\geq 10$ & & 37 (33\%) & 75 (67\%) & $P=0.038 * *$ \\
\hline
\end{tabular}

Notes: $* T$-test; $* *$ Fisher's exact test. Abbreviation: NOK, Norwegian krone.
As for hepatitis B, one woman (1\%) and two men (2\%) were anti-HBc and $\mathrm{HBsAg}$ positive. Five of the women (4\%) and seven of the men $(6 \%)$ were only anti-HBc positive. All of these 15 hepatitis B-affected couples were discordant (Table 3).

Eight of the women (7\%) and 14 of the men (13\%) were both anti-HBc positive and anti-HBs positive. Only one couple was concordant (Table 3).

\section{Discussion}

To our knowledge, this is the first study about STIs among Pakistani immigrants in Norway. In our couples, C. trachomatis and HSV-2 were not prevalent. Since our testing was based on serological samples and detection of antibodies, it reflects what has happened during their lifetime and the great majority of our men and women had never been infected with these STIs.

Pakistani women in our study came to Norway for marriages. We did not ask about their husbands' sexual behavior. In Vietnam, women with low education or low economic status had less knowledge of STI than those with higher education or high income. Unmarried women and those under the age of 20 years demonstrated the lowest level of STI knowledge. ${ }^{16}$

All pregnant women in Norway are tested for HIV. None of the Pakistani pregnant women in our study were HIV positive. Therefore we did not examine their husbands' HIV IgG.

Hepatitis C virus (HCV) infection is not a common STI. Transmission of HCV occurs first and foremost through contaminated blood and blood products, blood transfusion, and contaminated syringes. Sexual transmission occurs, but is unusual. Vertical infection occurs, calculated risk is about $10 \% .{ }^{4}$ For these reasons we did not test HCV IgG.

Gonorrhea is a rare disease in Norway. ${ }^{4}$ Furthermore, no test is suitable for testing of Neisseria gonorrhoeae IgG.

We found only $1 \%$ C. trachomatis prevalence in females, but higher in men (12\%), and the couples were discordant. According to the producer's information, the sensitivity of the test used is $95 \%$, and the specificity $90 \%-91 \%$, compared to micro-immunofluorescence. Our findings indicate a much lower prevalence of $C$. trachomatis among both women and men of Pakistani origin compared to the general population of Norway with a reported prevalence of $9 \%-11 \%$ for women $15-24$ years old, and $21 \%$ for men 20-24 years old. ${ }^{7}$ In Australia, C. trachomatis prevalence was $7 \%$ in females and 5\% in males. ${ }^{17}$ Undocumented migrant status is also reported to be associated with higher risk of 
Table 2 Prevalence of Chlamydia trachomatis and HSV-2 lgG antibodies among Pakistani immigrant couples living in Norway

\begin{tabular}{|c|c|c|c|c|c|}
\hline Infection & $\begin{array}{l}\text { Women } \\
n=112\end{array}$ & $\begin{array}{l}\text { Men } \\
n=1 / 2\end{array}$ & Test* & $\begin{array}{l}\text { Concordant } \\
\text { infected couples }\end{array}$ & $\begin{array}{l}\text { Discordant } \\
\text { infected couples }\end{array}$ \\
\hline $\begin{array}{l}\text { Chlamydial lgG } \\
\text { present }\end{array}$ & I (I\%) & 13 (I2\%) & $P=1.000$ & 0 & I4 (I3\%) \\
\hline $\begin{array}{l}\text { HSV-2 lgG } \\
\text { present }\end{array}$ & $4(4 \%)$ & $2(2 \%)$ & $P=0.700$ & I (I\%) & $4(4 \%)$ \\
\hline
\end{tabular}

Note: *Fisher's exact test.

C. trachomatis prevalence. A study from Switzerland reported C. trachomatis to be three times more frequent in undocumented migrants $(13 \%)$ than in women with legal residency $(4 \%) .^{18}$

In our study, the seropositivity of HSV-2 was low, $4 \%$ in women and $2 \%$ in men. According to the producer's information, the sensitivity of the test used is $96.1 \%$, and specificity is $97 \%$, compared with Western blot. The prevalence of HSV-2 was $17 \%$ in STI patients and $14 \%$ in pregnant women in Norway. ${ }^{10}$ Prevalence of HSV-2 infection was $34.8 \%$ in northern California. Black race, older age, lower income, parity, greater number of lifetime male sexual partners, earlier onset of sexual intercourse, sex work, history of STI, and cocaine use were factors associated with HSV-2 positivity. ${ }^{19}$ In Israel, the prevalence of HSV-2 infection was $13.3 \%$, and the rate was threefold higher among immigrants from the former Soviet Union (27.5\%) than among Israeli-born Jewish and Arab women (9\%). The role of high-risk sexual behavior in the spread of the infection has been reconfirmed. ${ }^{20}$

Twelve percent of women and $21 \%$ of men were or had been infected with hepatitis B. Since HBV infection in this population often is acquired at birth or in childhood, this infection cannot be regarded as a measure of STIs.

A Norwegian report from 2007 showed that immigrants had higher risk of diseases, in particular severe infectious diseases. ${ }^{21}$ The first cause presuming immigrants to be a group especially exposed to extra burden due to their situation as immigrants. The second is that living conditions among immigrants are generally worse than in the majority population. They have lower income, are more likely to be unemployed, have worse housing situations, and lower educational level. Immigrants from low-income countries have higher prevalence of hepatitis B, HIV, and tuberculosis which reflect their situation in their home country. They are usually infected before they come to Norway, or they get infected when they visit their home countries. ${ }^{21}$ In our study, there was also a tendency towards more infections among persons with low income or low education level. Due to the relatively small sample the results only reached significance for the association of hepatitis B in women with low education level.

From 1991, World Health Organization (WHO) recommended all member countries to introduce $\mathrm{HBV}$ vaccine in their immunization programs. With recent dramatic increases in $\mathrm{HBV}$ vaccine production and decreases in the price, global HBV infection rates may be reduced by as much as $90 \%$ over the next 10 years..$^{22}$ In our study, under $1 \%$ of the women and $2 \%$ of the men were positive for $\mathrm{HBsAg}$, which means their blood, cervical secretion, and sperm are infectious. Four percent of the women and $6 \%$ of the men were positive for anti-HBc only, possibly low-level HBV infection, and risk of transmission could not be excluded. In Pakistan, almost $2 \%$ were positive for HBsAg, being in the same range as among our Pakistani immigrants. ${ }^{23}$ In 2005, Norwegian Institute of Public Health estimated that we had $12,000-15,000 \mathrm{HBV}$ carriers $(<0.5 \%) .{ }^{14}$ A majority of these are immigrants from high and middle endemic areas, plus drug addicts. A Norwegian working group has recently suggested including HBV vaccination in our national program. ${ }^{24}$

Table 3 Serological status of HBV among 112 pairs of Pakistani immigrants in Norway

\begin{tabular}{|c|c|c|c|c|c|}
\hline Hepatitis B & $\begin{array}{l}\text { Women } \\
n=112\end{array}$ & $\begin{array}{l}\text { Men } \\
n=112\end{array}$ & Test* & $\begin{array}{l}\text { Concordant } \\
\text { infected couples }\end{array}$ & $\begin{array}{l}\text { Discordant } \\
\text { infected couples }\end{array}$ \\
\hline $\mathrm{HBsAg}$ positive & $\mathrm{I}(\mathrm{I} \%)$ & $2(2 \%)$ & $P=1.000$ & 0 & $3(3 \%)$ \\
\hline \multicolumn{6}{|l|}{ Anti-HBc positive "carrier" } \\
\hline Anti-HBc positive & $5(4 \%)$ & $7(6 \%)$ & $P=1.000$ & 0 & $12(11 \%)$ \\
\hline $\begin{array}{l}\text { Anti-HBc and anti-HBs positive } \\
\text { "previous infection" }\end{array}$ & $8(7 \%)$ & 14 (13\%) & $P=0.414$ & I (I\%) & $20(18 \%)$ \\
\hline
\end{tabular}

Note: *Fisher's exact test. 
Table 4 Factors associated with Chlamydia trachomatis, HSV-2, and hepatitis B seropositivity among Pakistani pregnant women and their husbands in Norway

\begin{tabular}{|c|c|c|c|c|}
\hline Factor & Positive IgG & Negative IgG & Total & $\begin{array}{l}\text { Crude odds ratio } \\
\text { (95\% confidence interval) } \\
\text { unadjusted }\end{array}$ \\
\hline \multicolumn{5}{|l|}{ C. trachomatis, men } \\
\hline \multicolumn{5}{|l|}{ Age, years } \\
\hline$\geq 25$ & II (II) & $86(89)$ & $97(100)$ & 1 \\
\hline$<25$ & $2(13)$ & $13(87)$ & $15(100)$ & $1.2(0.2-6.1)$ \\
\hline \multicolumn{5}{|l|}{ Educational level } \\
\hline$\geq 9$ years of school & $8(11)$ & $68(89)$ & $76(100)$ & 1 \\
\hline$<9$ years of school & $5(14)$ & $3(86)$ & $36(100)$ & $1.4(0.4-4.5)$ \\
\hline \multicolumn{5}{|l|}{ Family income, NOK } \\
\hline$\geq 300,000$ & $9(15)$ & $50(85)$ & $59(100)$ & 1 \\
\hline$<300,000$ & $4(8)$ & $49(92)$ & $53(100)$ & $0.5(0.1-1.6)$ \\
\hline \multicolumn{5}{|l|}{ HSV-2, women } \\
\hline \multicolumn{5}{|l|}{ Age, years } \\
\hline$\geq 25$ & $4(6)$ & $66(94)$ & $70(100)$ & 1 \\
\hline$<25$ & 0 & $42(100)$ & $42(100)$ & 0 \\
\hline \multicolumn{5}{|l|}{ Educational level } \\
\hline$\geq 9$ years of school & $3(6)$ & $50(94)$ & $53(100)$ & I \\
\hline$<9$ years of school & I (2) & $58(98)$ & $59(100)$ & $0.3(0.1-2.9)$ \\
\hline \multicolumn{5}{|l|}{ Family income, NOK } \\
\hline$\geq 300,000$ & I (2) & $58(98)$ & $59(100)$ & 1 \\
\hline$<300,000$ & $3(6)$ & $50(94)$ & $53(100)$ & $3.5(0.4-35.0)$ \\
\hline \multicolumn{5}{|l|}{ HSV-2, men } \\
\hline \multicolumn{5}{|l|}{ Age, years } \\
\hline$\geq 25$ & $2(2)$ & $95(98)$ & $97(100)$ & 1 \\
\hline$<25$ & 0 & $15(100)$ & $15(100)$ & 0 \\
\hline \multicolumn{5}{|l|}{ Educational level } \\
\hline$\geq 9$ years of school & $2(3)$ & $74(97)$ & $76(100)$ & I \\
\hline$<9$ years of school & 0 & $36(100)$ & $36(100)$ & 0 \\
\hline \multicolumn{5}{|l|}{ Family income, NOK } \\
\hline$\geq 300,000$ & $2(3)$ & $57(97)$ & $59(100)$ & I \\
\hline$<300,000$ & 0 & $53(100)$ & $53(100)$ & 0 \\
\hline \multicolumn{5}{|l|}{ Hepatitis B, women } \\
\hline \multicolumn{5}{|l|}{ Age, years } \\
\hline$\geq 25$ & $9(13)$ & $61(87)$ & $70(100)$ & 1 \\
\hline$<25$ & $5(12)$ & $37(88)$ & $42(100)$ & $0.9(0.3-3.0)$ \\
\hline \multicolumn{5}{|l|}{ Educational level } \\
\hline$\geq 9$ years of school & $3(6)$ & $50(94)$ & $53(100)$ & 1 \\
\hline$<9$ years of school & $11(19)$ & $48(8 \mathrm{I})$ & $59(100)$ & $3.8^{*}(1.0-14.5)$ \\
\hline \multicolumn{5}{|l|}{ Family income, NOK } \\
\hline$\geq 300,000$ & $9(15)$ & $50(85)$ & $59(100)$ & I \\
\hline$<300,000$ & $5(9)$ & $48(9 I)$ & $53(100)$ & $0.6(0.2-1.9)$ \\
\hline \multicolumn{5}{|l|}{ Hepatitis B, men } \\
\hline \multicolumn{5}{|l|}{ Age, years } \\
\hline$\geq 25$ & $22(23)$ & $75(77)$ & $97(100)$ & I \\
\hline$<25$ & I (7) & $14(93)$ & $15(100)$ & $0.2(0.3-2.0)$ \\
\hline \multicolumn{5}{|l|}{ Educational level } \\
\hline$\geq 9$ years of school & $14(18)$ & $62(82)$ & $76(100)$ & I \\
\hline$<9$ years of school & $9(25)$ & $27(75)$ & $36(100)$ & $4.1(0.5-33.0)$ \\
\hline \multicolumn{5}{|l|}{ Family income, NOK } \\
\hline$\geq 300,000$ & $10(17)$ & $49(83)$ & $59(100)$ & I \\
\hline$<300,000$ & $13(25)$ & $40(75)$ & $53(100)$ & $1.6(0.6-4.0)$ \\
\hline
\end{tabular}

Abbreviation: NOK, Norwegian krone. 
The occurrence of "anti-HBc only positive" represents a special problem and raises some questions. HBV DNA determination in single samples is of limited value. Of the anti-HBc only positives, about $5 \%$ will be DNA positive with polymerase chain reaction, the percentage may show some variation according to ethnic origin. Furthermore, the viremia level may vary between detectable and undetectable over time. Therefore we usually do not recommend DNA testing, and did not perform such testing in our material. From a public health standpoint, it is more meaningful to recommend vaccination to sexual partners and family members, and to give specific immunoglobulin and vaccine to the newborns of anti-HBc only, positive mothers.

Pakistani women in Norway with low education was a risk group for hepatitis B infection.

There was also a tendency among men, but the results did not reach significance (Table 4).

We did not find any specific factors associated with seropositivity for $C$. trachomatis and HSV-2 among Pakistani immigrant couples in Norway (Table 4).

\section{Conclusion}

STIs were not prevalent in Pakistani immigrant couples in Norway. However, it was striking that when one partner was positive, the other was not, so most couples were discordant. More men than women had undergone C. trachomatis infection, they possibly had earlier sexual experiences before marriage, and the women may not have or are not having concurrent sexual experiences. The men either had $C$. trachomatis before the marriage and cleared the infection or had it during the marriage and cleared it before transmitting to the wife. One should pay attention to hepatitis B among Pakistani immigrants. WHO has recommended including $\mathrm{HBV}$ vaccine in the immunization programs.

Meanwhile, Pakistani immigrants who are unprotected against infection should be offered HBV vaccine and newborn children whose mothers are HBsAg positive or only anti-HBc positive should be treated with immunoprophylaxis and vaccine shortly after delivery.

\section{Acknowledgments}

The authors thank the women and men who participated in the study, and the midwives and assistants in the prenatal clinic who facilitated the data collection.

Also thanks to Tone Berge, Grete Bergsaker, Zeidad Fernandez, Liv Jørgensen, Anne Britt Lerkerød, Solveig
Løtveit, Azel Pettersen, and Gro Presterud for their excellent technical assistance.

The study was supported by Norwegian Women's Public Health Association, Letten Foundation, and Institute of General Medicine, University of Oslo.

\section{References}

1. Statistisk sentralbyrå (Statistics Norway). 2009. Available from: http://www.ssb.no/innvandring/ Accessed Aug 14, 2010.

2. Sami S, Baloch SN. Vaginitis and sexually transmitted infections in hospital based study. J Pak Med Assoc. 2005;55(6):242-244.

3. Fenton KA, Mercer CH, McManus S, et al. Ethnic variations in sexual behavior in Great Britain and risk of sexually transmitted infections: a probability survey. Lancet. 2005;365(9466):1246-1255.

4. Norwegian Institute of Public Health. 2010. Handbook in infection protection for municipal health services. Available from: www.fhi.no/ smittevernhandbok. Accessed Aug 6, 2010.

5. Millman K, Black CM, Johnson RE, et al. Population-based genetic and evolutionary analysis of Chlamydia trachomatis urogenital strain variation in the United States. J Bacteriol. 2004;186(8):2457-2465.

6. Hu D, Hook EW, Goldie SJ. Screening for Chlamydia trachomatis in women 15 to 29 years of age: a cost-effectiveness analysis. Ann Int Med. 2004;141(7):501-513

7. Bakken IJ, Nordbø SA, Skjeldestad FE. Chlamydia trachomatis testing patterns and prevalence of genital chlamydial infection among young men and women in central Norway 1990-2003: a population-based registry study. Sex Transm Dis. 2006;33(1):26-30.

8. Rodriques J, Grinsztejn B, Bastos FI, et al. Seroprevalence and factors associated with herpes simplex virus type 2 among HIV-negative high-risk men who have sex with men from Rio de Janeiro, Brazil: a cross-sectional study. BMC Infect Dis. 2009;9:39.

9. Torres G, Schinstine M, Krusinski P, Tyring SK; Medscape. Herpes simplex. August, 2009. Available from: http://emedicine.medscape. com/article/1132351-overview. Accessed Aug 6, 2010.

10. Nilsen A, Mwakaglie D, Marsden H, Langeland N, Matre R, Haarr L. Prevalence of, and risk factors for, HSV-2 antibodies in sexually transmitted disease patients, healthy pregnant females, blood donors, and medical students in Tanzania and Norway. Epidemiol Infect. 2005; 133(5):915-925.

11. Alam MM, Zaidi SZ, Naeem SA, et al. Serology based disease status of Pakistani population infected with Hepatitis B virus. BMC Infect Dis. 2007;7:64.

12. Russi JC, Serra M, Vinoles J, et al. Sexual transmission of hepatitis B virus, hepatitis $C$ virus, and human immunodeficiency virus type 1 infections among male transvestite commercial sex workers in Montevideo, Uruguay. Am J Trop Med Hyg. 2003;68(6):716-720.

13. Arevalo JA. Hepatitis B in pregnancy. West J Med. 1989;150(6): 668-674.

14. Norwegian Institute of Public Health. Handbook in infection protection for municipal health services. 2005. Available from: www.fhi.no/ smittevernhandbok. Accessed Aug 6, 2010.

15. Cuniato V, Bellitti F, Di Martino M, Nocera E, Esposito S, Noviello S. [Immigration and sexually transmitted diseases: risk factors, prevention, and health education]. Infez Med. 2001;9(4):226-231. Italian.

16. Lan PT, Lundborg CS, Mogren I, Phuc HD, Chuc NT. Lack of knowledge about sexually transmitted infections among women in North rural Vietnam. BMC Infect Dis. 2009;9:85.

17. Kong FY, Hocking JS, Link CK, Chen MY, Hellard ME. Sex and sport: chlamydia screening in rural sporting clubs. BMC Infect Dis. 2009; 9:73.

18. Wolff H, Lourenco A, Bodenmann P, et al. Chlamydia trachomatis prevalence in undocumented migrants undergoing voluntary termination of pregnancy: a prospective cohort study. BMC Public Health. 2008; 8:391. 
19. Buchacz K, McFarland W, Hernandez M, et al. Prevalence and correlates of herpes simplex virus type 2 infection in a population-based survey of young women in low-income neighborhoods of Northern California. The Young Women's Survey Team. Sex Transm Dis. 2000; 27(7):393-400.

20. Dan M, Sadan O, Glezerman M, Raveh D, Samra Z. Prevalence and risk factors for herpes simplex virus type 2 infection among pregnant women in Israel. Sex Transm Dis. 2003;30(11):835-838.

21. Norwegian Institute of Public Health. Næss Ø, Rognerud M, Strand BH, editors. Sosial Ulikhet; helse. En faktarapport. Rapport 2007;1:41, 43. (Norwegian).
22. Maynard JE. Hepatitis B: global importance and need for control [discussion]. Vaccine. 1990;8 Suppl:S21-S23.

23. Jafri W, Jafri N, Yakoob J, et al. Hepatitis B and C: prevalence and risk factors associated with seropositivity among children in Karachi, Pakistan. BMC Infect Dis. 2006;6:101.

24. Norwegian Institute of Public Health. Anbefalinger for bruk av Hepatitt B-vaksine; Norge. Arbeidsgruppe for vurdering av bruken av Hepatitt B vaksine. Rapport 2008;9:7.

International Journal of Women's Health

\section{Publish your work in this journal}

The International Journal of Women's Health is an international, peerreviewed open-access journal publishing original research, reports, reviews and commentaries on all aspects of women's healthcare including gynecology, obstetrics, and breast cancer. Subject areas include Chronic conditions (migraine headaches, arthritis, osteoporosis);

\section{Dovepress}

Endocrine and autoimmune syndromes; Sexual and reproductive health; Psychological and psychosocial conditions. The manuscript management system is completely online and includes a very quick and fair peer-review system. Visit http://www.dovepress.com/ testimonials.php to read real quotes from published authors.

Submit your manuscript here: http://www.dovepress.com/international-journal-of-womens-health-journal 